\title{
Eco-Efficiency Products: A Guideline for Teak Utilization Over 13-15 Years
}

\author{
Theerathat Lertchamchongkul \\ Songwut Egwutvongsa* \\ Department of Architectural Education and Design, \\ King Mongkut's Institute of Technology Ladkrabang, \\ 1 Chalong Krung 1 Alley, Lat Krabang, \\ Bangkok 10520, Thailand \\ ${ }^{*}$ Corresponding Author
}

DOI: https://doi.org/10.36941/ajis-2022-0038

\begin{abstract}
The objective of this research was to develop a guideline for teak utilization over 13-15 years. In this case, the population comprised one thousand, one hundred, and twenty-nine participants at the academic conference and Thai natural resource exhibition, while the group sampling included a visitor group comprising ninetyfour people at the exhibition and young teak product sales at the level of deviation of 1o percent. In this case, a 5-point rating scale was used as a research tool employing structured questionnaires, with a reliability value at the level of 0.7842 . The results found that the participants had satisfaction in the produced model from young teak at the excellent level, (Mean=4.202; S.D. $=0.649)$ according to the eight fields of satisfaction assessment consisting of 1) Function, 2) Durability, 3) Economics, 4)Material, 5)Ease of Use, 6)Construction, 7)Aesthetics, and 8)Production. Therefore, there were the means of each satisfaction field at the same level with a significance of .05, and the research results in the community group could be applied to use with the utilization pattern of young teak for 13-15 years by increasing economic value for teak garden cultivation in various communities.
\end{abstract}

Keywords: Creativity, Development, Eco-efficiency, Product, Teak, Utilization

\section{Introduction}

Teak is a valuable kind of wood in the economy. In the past, it was an export product with earnings income for Thailand, following rice product. Moreover, the teak in Thailand usually grows in the areas of mixed forest in the northern and central regions of the country. Unfortunately, there have been high numbers of illegally cut down teak trees in the conservation areas each year, thus becoming a big problem for the communities and people living nearby the conservation forests throughout Thailand.

Furthermore, the problem of the reduced number of natural teak tree numbers has resulted in higher prices in the markets. Thus, the government sector of Thailand has realized an opportunity to solve the problem with the local people living near the conservation forests. Besides, the government sector has promoted policies to allow the people to cultivate the economic teak trees in their own agriculture areas by earning income with eco-efficiency guidelines as one alternative (Poti, T. et al., 
2020). This case can contribute to the creation of learning for the environment of the community to gain economic benefit by increasing the income for the people in the community due to the utilization of sustainable teak tree cultivation (Mas, S. R. et al., 2021).

One solution for the illegally cut down teak trees in the community is by increasing the income for teak tree cultivation in the agricultural areas of the Thai government. In this case, it conforms to the concept of the United Nations to propose guidelines for sustainable forest management by maintaining the teak trees as conservation forest resources, including leveling up income and economic value by cultivating teak trees for additional income. The people will have stabilization in agricultural occupations as well as building the teak tree forest or economic cultivation with one hundred thousand rai in each year. Particularly, it will help solve the integration problem by gaining a higher level of forest resources. Later, the teak trees can be sold at high value in the markets based on the requirements. After the agriculturists have cut down the trees to be sold, they could be replanted from cutting out the tree bodies and gradually adding new ones. Thus, it is involved with the circulation system of teak resources of Thailand with gaining incomes at high ratios, including promoting the agriculturists to cultivate teak trees by applying eco-efficiency guidelines for the forest management principle in responding to current and future requirements (Van-Ness, N. \& Cramer, J., 2005; Aleban, N. A., 2021). Therefore, this can create balance between the conservation and sustainable utilization according to the convention of biodiversity and universal union of conservation (IUCN) with sustainable forest management, biodiversity, and livelihoods. Further, the focus should be on the proper environment for lifestyles with earning good incomes by cultivating with eco-efficiency teak trees to respond to currently effective requirements and building for the abundant forest resources in the future as one alternative.

This research aimed to present a study of young teak properties by applying the knowledge of young teak properties over 13-15 years in creative community products. In this case, they can be cultivated for producing and selling at suitable levels based on the integration method by promoting and developing for quality of life under the Conservation for Plant Genetics Foundation as well as the Food and Agriculture Organization of the United Nations or FAO and International Teak Network (TEAKNET). Then, it must stimulate the people with eco-efficiency teak tree cultivation to gain transformative knowledge of the worthy resources, including the utilization of young teak over 13-15 years with good effectiveness. After that, it contributes to stabilization due to direct as well as indirect biodiversity (Egwutvongs, S. et al., 2021). This is based on the people participating in the community, utilizing the economic teak trees to respond in the fields of economics, civilization, technology and environment. As a result, agriculturists will be capable of increasing values by decorating the bodies and cutting them to expand the spaces, thus growing plants for gaining higher incomes while reducing the number of illegally cut down teak trees, which will promote the environments to be utilized sustainably.
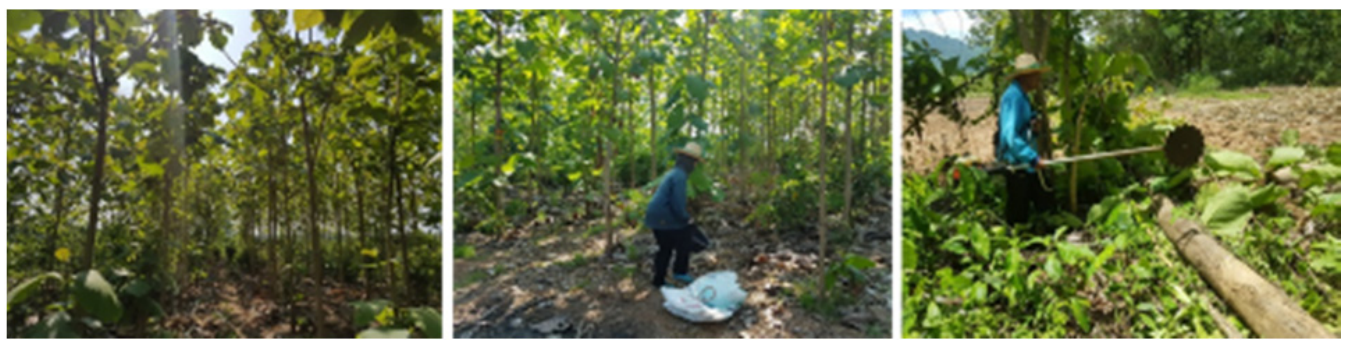

Figure 1: Teak cultivation in agricultural areas by agriculturists

Source: Author 


\section{Methodology}

\section{$2.1 \quad$ Research Objectives}

$>$ To develop young teak products over 13-15 years

$>$ To undertake a satisfaction assessment for customers concerning teak products over 13-15 years

\subsection{Scope}

This method involved research and development (R\&D) by focusing on teak products development over 13-15 years; it is based on the potential learning about young teak materials from the information of the new designing product patterns:

$>$ It is the studying step of the physical properties from teak over $13-15$ years in the forest gardens from the economic teak cultivation at the testing area of Thong Pha Phum District, Kanchanaburi Province by considering specific properties: 1)Moisture, Content, 2)Density, and 3)Specific Gravity.

$>$ It is the development step for product patterns conforming to the teak properties over 13-15 years as the case study in Thong Pha Phum District in Kanchanaburi Province by considering the information from the research informants.

The population group comprised agriculturists manufacturing teak products in Huai Huay Kyoeng Sub-District, Thong Pha Phum District in Kanchanaburi Province, totaling 501 people.

Group sampling is the agriculturist group manufacturing teak products in Huai Huay Kyoeng Sub-District, Thong Pha Phum District in Kanchanaburi Province, totaling 84 people, by using the random table of Taro Yamane at the level of deviation of 10 percent in Stratified Random Sampling.

The research tool is a structured questionnaire or close-ended form for teak product development over 13-15 years by using a 5-point rating scale assessment; the results of quality analysis for the research tool had a reliability level of 0.7623 by using the analysis information of means, standard deviation, and t-test independent.

$>$ It is related to the satisfaction assessment steps and comparison of satisfaction level to customers with produced teak products over 13-15 years in the case study of Thong Pha Phum Sub-District in Kanchanaburi Province by considering the information from the research informants.

The population group comprised 1,129 visitors to the exhibition and the young teak product sales of King Mongkut's Institute of Technology Ladkrabang at the academic conference and 9th exhibition of Thai natural resources located at Chulalongkorn University Saraburi Campus, Champhakpraew Sub-District, Kang Khoi District in Saraburi Province during three days of participation.

Group sampling comprised a group of 94 visitors to the exhibition and the young teak product sales of King Mongkut's Institute of Technology Ladkrabang. The Random Table of Taro Yamane was used with the level of deviation at 10 percent and the Table of Random Numbers from computers by selecting from the standard of registered ones with activities each day.

The research tool is the structured questionnaire or close-ended form of satisfaction after testing to use the teak products over 13-15 years with a 5-point rating scale assessment; the results of the research quality analysis had reliability at the level of 0.7842 , represented as collected data from means, standard deviation, and One-way ANOVA.

\subsection{Research Framework}

1] Framework 1: It is involved with the creative designing steps of teak products for 13-15 years (Moalosi, R. et al., 2010; Conti, E. \& Chiarini, A., 2021). In this case, it is based on the principle of the product for environments connecting between the new product development patterns and 
environmental management. This is done by considering the life cycle of products with the environmental effects and other factors that are significant to the product design: 1) Product Economics, 2) Customer Requirements, 3) Manufacturability, and 4) Required product functions (Shree, D. et al., 2017; Liu, J. et al., 2021; Kuys, J. et al., 2021).

2] Framework 2: It is involved with the satisfaction assessment steps and the comparison of satisfaction level for customers. This research is based on the principle of young teak product design in eco-efficiency consisting of standards including 1) Function, 2) Durability, 3) Economics, 4) Material, 5) Construction, 6) Ease of Use, 7) Aesthetics, and 8) Production (Lai, X. et al., 2007; Gustafsson, S.I., 1995).

\section{Results}

1) According to the results of the physical properties, the experiment was carried out at the forest park after cultivation in Thong Pha Phum Sub-District, Kanchanaburi Province.
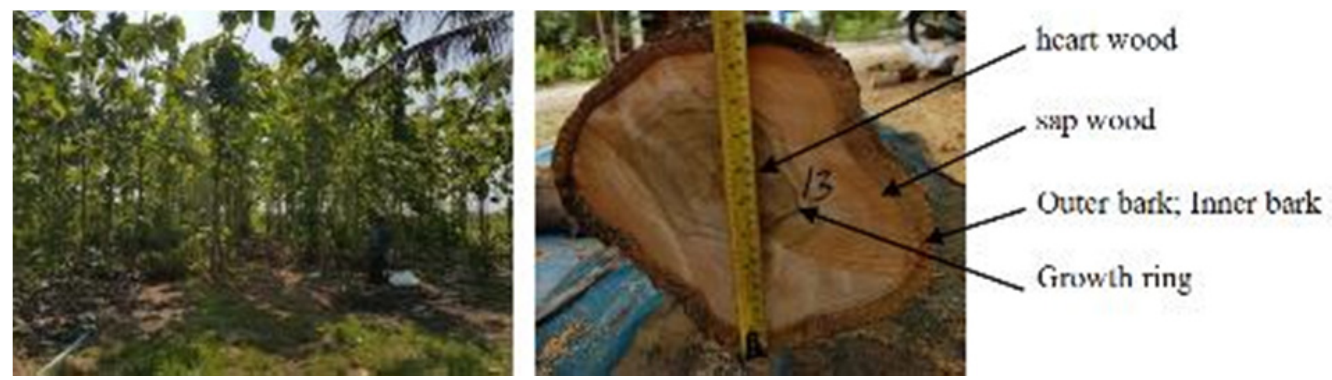

Figure 2: Cutting Procedure of Teak Cultivation by Expanding the Spaces

Source: Author

According to the analysis of teak attributions by cutting to expand the spaces and applying the teak trees with 13-15 years into the transformation procedure, it showed different physical properties as follows: 1) Attributions, 2) Surfaces, 3) Sizes, and 4) Strength. In this case, it represented the different properties from the teak conditions, especially for the growth ring as an important aspect with clarity and beauty according to the market requirements with the age periods. Therefore, the details are shown according to the analysis of the mechanical properties for teak over 13-15 years in the dried condition and the density level with 12 percent. This includes 1) Modulus Rupture in the level of 100 megapascals, 2) Flexible Modulus in the level of 10 megapascals, and 3) Perpendicular Compressive Strength of Bur in the level of 0.39 megapascals, as well as 4) Parallel Compression of Bur, 5) Shear Value in the level of 49 megapascals, and 6) Strength Value in the level of 4,864 Newtons and the Stickiness Value at the level of 1.70 kilograms per meters. As a result, it was found that teak over 13-15 years from the forest park in the eco-efficiency cultivation had natural durability in the low to the medium level compared to the teak trees in natural forests with a high durability level from natural conditions.

Table 1: Physical Property Test of Forest Plantation Teak

\begin{tabular}{|c|l|c|}
\hline Order & List & Testing Result \\
\hline 1. & Moisture Content & 11.83 \\
\hline 2. & Density & 0.57 \\
\hline 3. & Specific Gravity & 0.51 \\
\hline
\end{tabular}

* Case Study in the Cultivation Area of Thong Pha Phum District, Kanchanaburi Province over 13-15 Years

Source: Author 
According to the analysis results for teak properties over 13-15 years, it represented the moisture content equal to 11.83 percent with density and volume mass equal to $0.57 \mathrm{gram} / \mathrm{cm}^{3}{ }^{3}$ with the specific gravity that is the ratios between the wood weight and the water capacity equal to 0.51 .

$>$ Applying Knowledge from Teak Properties between 13-15 Years in the Young Teak Product Manufacturing by forming a conclusion with five fields of details

Table 2: Application of Young Teak Properties into Creative Works

\begin{tabular}{|c|c|c|c|c|c|c|c|}
\hline \multirow[t]{2}{*}{ Detail } & \multirow{2}{*}{$\begin{array}{c}\text { Teak Properties over 13-15 years } \\
\text { in the case study of the Forest Park at Thong } \\
\text { Pha Phum Sub District } \\
\text { in Kanchanaburi Province }\end{array}$} & \multicolumn{3}{|c|}{$\begin{array}{l}\text { Suitability Level of } \\
\text { Fumiture }\end{array}$} & \multicolumn{3}{|c|}{$\begin{array}{l}\text { Suitability Level of } \\
\text { Internal Decoration }\end{array}$} \\
\hline & & Most & Medium & Less & Most & Medium & Less \\
\hline \multirow{2}{*}{$\begin{array}{l}\text { Teak } \\
\text { Texture }\end{array}$} & The wood texture is soft without strength. & & $\bullet$ & & $\bullet$ & & \\
\hline & $\begin{array}{l}\text { The wood texture has a softer weight than } \\
\text { normal with over } 15 \text { years. }\end{array}$ & - & & & 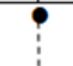 & & \\
\hline \multirow[t]{3}{*}{ Durability } & The durability of wood can be bent. & 6 & & & 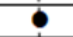 & & \\
\hline & The durability of wood can be formed. & -.. & & & •.. & & \\
\hline & $\begin{array}{l}\text { Wood durability cannot be placed with an } \\
\text { attachment. }\end{array}$ & & & & & 甲 & \\
\hline \multirow[t]{3}{*}{ Strength } & The wood strength has action force. & & 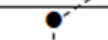 & & & $\phi$ & \\
\hline & The wood is small with less body width. & & 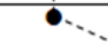 & & & i & \\
\hline & The wood has a soft surface. & & & $\bullet$ & & a. & \\
\hline \multirow[t]{4}{*}{$\begin{array}{l}\text { Texture } \\
\text { Properties }\end{array}$} & $\begin{array}{l}\text { Attachment with a nail and screw has less } \\
\text { value. }\end{array}$ & & & 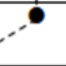 & & & \\
\hline & $\begin{array}{l}\text { It cannot be placed or attached at a high } \\
\text { level. }\end{array}$ & & & & & & \\
\hline & $\begin{array}{l}\text { The wood texture in the rim has a high level } \\
\text { of flexibility. }\end{array}$ & & $\bullet$ & & $\bar{\varphi}$ & & \\
\hline & $\begin{array}{l}\text { It should increase the washing and drying } \\
\text { procedures. }\end{array}$ & & 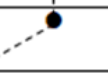 & & $\phi$ & & \\
\hline \multirow[t]{2}{*}{$\begin{array}{l}\text { Physical } \\
\text { Texture }\end{array}$} & $\begin{array}{l}\text { It has beautiful colors with a clear growth } \\
\text { ring appearance. }\end{array}$ & $\bar{\varphi}$ & & & $\phi$ & & \\
\hline & It shows the uniqueness of teak colors. & $\bullet$ & & & - & & \\
\hline & Consideration for Consistency & \multicolumn{3}{|c|}{2.357} & \multicolumn{3}{|c|}{2.500} \\
\hline
\end{tabular}

Source: Author

According to the suitability of applying the teak over 13-15 years, it can be analyzed conforming to creation. Besides, it was found that the suitability level to the furniture manufacturing was at the excellent level of Means, (Mean=2.357; from Measuring with Three Levels). This case represented the suitability level to apply with the internal decoration inside residences at an excellent level of Means, (Mean=2.500, From Measuring with Three Levels). It was also found that the physical properties of the young teak still had limitations for applying at a high level, except for the beauty, uniqueness and the wood pattern clearness as good features. As a result, it can be accounted for as an attraction for being the favorite furniture in the internal decoration markets for the Asia continent (Xiong, X. et al., 2020; Jiang, L. et al., 2020).

2) According to the results of the product pattern development step, it has taken the assessment of the suitability of the teak properties between 13-15 years in the case study of Thong Pha Phum SubDistrict in Kanchanaburi Province. Besides, it used the creative idea procedure to present the internal decoration works in the residents; it conforms to the young teak properties with high weakness and the soft capacity to a place of the wood surface, especially to be fitted for applying with beauty. In this case, it is contributing to increasing the value of economic materials at an excellent level with the creative concept idea of designing procedures. This includes 1) the conclusion of limitations on physical attributions of the young teak materials, 2) the presentation of the basic concept idea, 3) the 
conclusion and regulations of details, 4) the creative model to be tested, and 5) the test of customer usage and others. Thus, these five steps are concerned with the response of the customer requirements at the highest level (Obinna, F. P. et al., 2021).
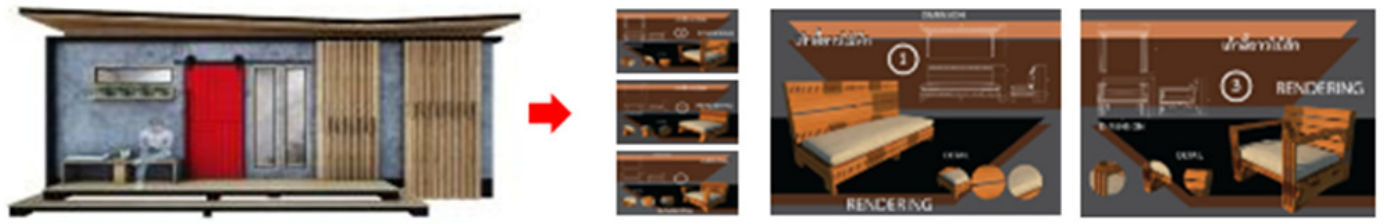

Figure 3: Design Product from Teak Utilization over 13-15 Years

Source: Author

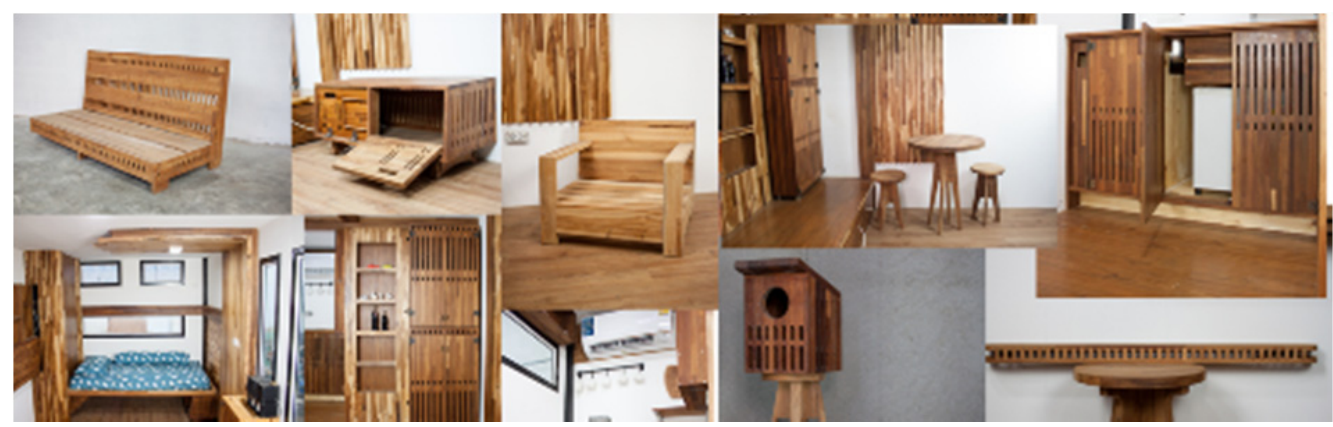

Figure 4: Product Model Creation and Teak Decoration over 13-15 years

Source: Author

According to the designing procedure objectives, it can suggest the young teak utilization by representing the internal decoration utilization in residences with the integration of teak tree uniqueness from the beautiful colors and the year circles. Thus, it becomes a good feature of the furniture products and the internal decoration of the real models by testing from the customer groups and the teak product manufacturer groups.
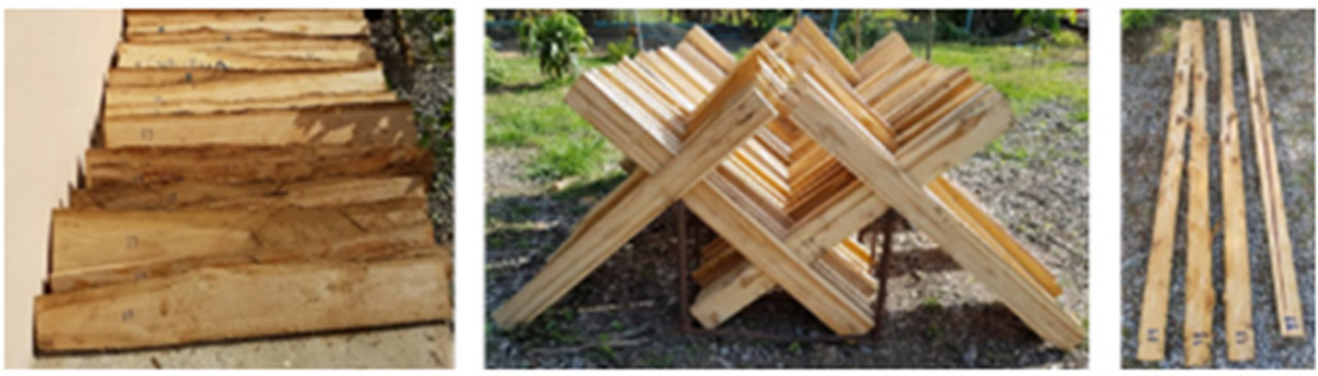

Figure 5: Transformed Teak Trees over 13-15 years Before Drying to Reduce Density and Prevent Bending

Source: Author 
Table 3: Satisfaction Assessment of the Internal Decoration Model from Young Teak

\begin{tabular}{|l|c|c|c|c|c|c|}
\hline \multirow{2}{*}{ Assessment List } & \multicolumn{2}{|c|}{$\begin{array}{c}\text { Customer } \\
\text { Group }\end{array}$} & \multicolumn{2}{c|}{$\begin{array}{c}\text { Manufacturer Group of Teak } \\
\text { Products }\end{array}$} & \multicolumn{2}{c|}{ Comparison } \\
\cline { 2 - 7 } & Mean & S.D. & Mean & S.D. & t & Sig. \\
\hline 1. Suitability of Function & 4.00 & 0.64 & 3.67 & 0.72 & 3.179 & $.001^{*}$ \\
\hline 2. Suitability of Durability & 4.04 & 0.75 & 3.71 & 0.77 & 2.739 & $.003^{*}$ \\
\hline 3. Suitability of Economics in Manufacturing & 4.35 & 0.61 & 4.18 & 0.62 & 1.749 & .041 \\
\hline 4. Suitability with Material Efficiency & 4.55 & 0.52 & 4.21 & 0.66 & 3.625 & $.000^{*}$ \\
\hline 5. Ease of Use & 4.56 & 0.55 & 4.49 & 0.63 & 0.785 & .217 \\
\hline 6. Strength of Construction & 4.05 & 0.64 & 3.62 & 0.67 & 4.229 & $.000^{*}$ \\
\hline 7. Suitability of Aesthetics & 4.49 & 0.55 & 4.54 & 0.55 & 0.563 & .287 \\
\hline 8. Suitability of Quick Manufacturing Procedure & 3.96 & 0.50 & 3.32 & 0.66 & 7.096 & $.000^{*}$ \\
\hline Results & 4.25 & 0.65 & 3.97 & 0.78 & 7.196 & $.000^{*}$ \\
\hline
\end{tabular}

${ }^{*}$ Having a Statistical Significance Level of .01

Source: Author

According to the conclusion, it is involved with the comparison of satisfaction levels for the customer groups and the manufacturer groups of teak products after testing the model. In addition, it was found that the customer groups had an excellent level of satisfaction (Mean=3.97; S.D.=0.78), and after testing with t-test statistics, there were the means of satisfaction for the customer groups at the higher level than the teak product manufacturers with statistical significance at the level of .ol. In this case, when considering the minor subjects divided into the satisfaction opinions with statistical significance at the level of .o1, it was found in three fields including 1)Suitability of Economics in Manufacturing, 2)Ease of Use, and 3)Suitability of Aesthetics.

According to the customer groups and the manufacturer groups of teak products, it was similar to the statistical significance at the level of .o1 in five fields: 1) Suitability of Function, 2) Suitability of Durability, 3) Suitability with Material Efficiency, 4) Strength of Construction, and 5) Suitability of Quick Manufacturing Procedures.

Table 4: Satisfaction Assessment of Visitor Groups at the Exhibition of Academic Conference and $9^{\text {th }}$ Thai Natural Resources

\begin{tabular}{|l|l|c|c|c|c|}
\hline $\begin{array}{l}\text { Assessment } \\
\text { List }\end{array}$ & $\begin{array}{l}\text { Testing Method Prior to } \\
\text { Satisfaction Assessment }\end{array}$ & Mean & S.D. & S.E. & $\begin{array}{l}\text { Satisfaction } \\
\text { Level }\end{array}$ \\
\hline Function & Using the Model Area of Environment & 4.286 & 0.651 & 0.071 & Satisfied \\
\hline Durability & Testing to Use the Furniture Model & 4.155 & 0.591 & 0.064 & Satisfied \\
\hline Economics & Informing of Manufacturing Procedure with Selling Prices & 4.167 & 0.618 & 0.067 & Satisfied \\
\hline Materials & Informing about Teak Material Advantage Procedure & 4.060 & 0.665 & 0.073 & Satisfied \\
\hline Ease of Use & Using the Model Area of Environment & 4.202 & 0.617 & 0.067 & Satisfied \\
\hline Construction & Informing the Manufacturing Procedure and Material Selection & 4.179 & 0.604 & 0.066 & Satisfied \\
\hline Aesthetics & Using the Model Area of Environment & 4.250 & 0.790 & 0.086 & Satisfied \\
\hline Production & Informing the Manufacturing Procedure & 4.321 & 0.624 & 0.068 & Satisfied \\
\hline Overall Results of Eight Assessment Lists & 4.202 & 0.649 & 0.025 & Satisfied \\
\hline
\end{tabular}

Source: Author

According to the table, it was found that the test value for homogeneity of variances was shown as $[\mathrm{Bc}]=10.5883$; Sig. $=0.158$ with more than the level of .05 as the equal variance value for the populations. 
Table 5: Variance Analysis of Means for the Testing Groups

\begin{tabular}{|l|c|c|c|c|c|}
\hline & Sum of Squares & df & Mean Square & F & Sig. \\
\hline Between Groups & 4.0238 & 7 & 0.5748 & 1.3707 & 0.215 \\
\hline Within Groups & 278.4524 & 664 & 0.4194 & & \\
\hline Total & 282.4762 & 671 & & & \\
\hline
\end{tabular}

$\mathrm{CV}(\alpha=.05) ;$ F-table $=2.0234$

Source: Author

According to the analysis results of the table, it was found that the test of $F$ value for significance was shown as $F=0.215$ with more than the level of .05 . Further, the Means of satisfaction result for the visitors of the exhibition in the academic conference and 9th Thai natural resource with eight fields were not statistically significant at the level of .05.

Table 6: Comparison of Satisfaction Means for Visitors at the Exhibition of Academic Conference and Thai Natural Resources with Difference in Pairs as the LSD Method

\begin{tabular}{|l|c|c|c|c|c|c|c|c|}
\hline \multirow{2}{*}{ Assessment List } & \multicolumn{7}{|c|}{ p-value } & \multicolumn{7}{c|}{ ( } \\
\cline { 2 - 9 } & $\mathbf{1}$ & $\mathbf{2}$ & 3 & 4 & 5 & 6 & 7 & 8 \\
\hline 1. Function & & 0.174 & 0.226 & $0.027^{*}$ & 0.395 & 0.270 & 0.749 & 0.717 \\
\hline 2. Strength & & & 0.899 & 0.328 & 0.610 & 0.797 & 0.378 & 0.077 \\
\hline 3. Economics & & & & 0.281 & 0.708 & 0.900 & 0.447 & 0.108 \\
\hline 4. Materials & & & & & 0.151 & 0.226 & 0.093 & $0.009^{*}$ \\
\hline 5. Ease of Use & & & & & & 0.801 & 0.664 & 0.215 \\
\hline 6. Construction & & & & & & & 0.511 & 0.134 \\
\hline 7. Aesthetics & & & & & & & & 0.516 \\
\hline 8. Production & & & & & & & & \\
\hline
\end{tabular}

Source: Author

When using multiple comparisons, it showed the differences of satisfaction level in each field with two pair differences:

$>$ The first pair comparison showed the satisfaction on materials with the difference of function as statistical significance at the level of .05.

$>$ The second pair comparison showed the satisfaction on manufacturing with the difference of material as statistical significance at the level of .o5.

According to the research results, it showed that the design of eco-efficiency products is based on the guideline of teak utilization over 13-15 years as the case study of teak plots cultivation located in Huay Kyoeng Sub-District in Thong Pha Phum District of Kanchanaburi Province. After that, it brought the young teak from the cutting procedure to expand the teak cultivation spaces before being put into the markets. However, according to the over young teak on selling, it resulted in a lower selling price than the normal level. Similarly, the young teak can be applied as housing decoration and teak furniture, so the community groups and production technicians will learn about the limitations before transferring into the internal products of households. What is more, when testing with the transformation procedures to build the housing model of the environment from the young teak and the visitors of the exhibition in the academic conference and Thai natural resources, it showed that the overall assessment result was at the excellent level of satisfaction. As a result, it showed the differences between the satisfaction levels of two pairs in comparison when analyzing the result: 1) Material with differences in function, and 2) Manufacturing field with differences in materials. 


\section{Discussion and Conclusion}

According to the results of the physical properties for teak over 13-15 years at the forest park in Thong Pha Phum Sub-District, Kanchanaburi Province, it was found that there was soft weight with small particles in the growth ring and numerous sapwood. Besides, due to the soft texture or weak properties, it is called softwood without the suitability for applying hard force. Fortunately, it has uniqueness on the growth ring pattern from beauty and clearness (Purnomo, H. et al., 2009). It has a unique color pattern on the texture at the fitted level: 1) The soft weight of texture, 2) The beautiful and clear pattern, 3) The color to show the uniqueness and others. Thus, these three features can be integrated to apply for the natural resources with worthiness by making internal decoration work and furniture. Significantly, it is based on applying the product design principle with emphasis on the economic value by searching from the customer group requirements (Raymond L. B., 2013), including effective development from the young teak transformation procedure and biodiversity (Clark, G. et al., 2009). According to the limitations of the potential aspects of the material, however, it is a challenge for the designer to use the analysis procedure for creating sustainable development by utilizing the young teak over 13-15 years as the cutting step to expand the spaces in the economic cultivation (Howarth, G. \& Hadfield, M., 2006). Currently, guideline development with internal decoration from teak products is becoming a strategy to build competitive opportunity for the agriculturist groups of eco-efficiency by earning income and making the strength in lifestyles as well as being able to compete in the furniture market at a high level and with good suitability (Bumgardner, M. S. \& Nicholls, D. L., 2020; Egwutvongsa, S., 2021).

According to the prototype manufacturing process and the test by the customer groups and manufacturing groups with the teak products in the current market, (Wanneng, P. et al., 2014) the same opinion was observed from the potential limitation to apply in the internal decoration of residences or furniture with a soft surface force. This case enabled the determination of good product patterns before designing, creating, and making the model. Finally, it was tested by the customer groups and the manufacturing group. According to the results, it was found that the two groups had the satisfaction level to the guideline of the young teak applying in excellent level. On the contrary, according to the satisfaction level of the customer group it had a higher level of Means than the teak product manufacturers with statistical significance in the level of.o1 due to the different opinions: 1) Economic in manufacturing procedure 2) Ease of use, and 3) Aesthetics. Thus, according to the three fields from the different satisfaction levels for the young teak product procedure, it was congruent with the balancing principle at the most worthiness level in the natural resources beneficially to the people, the community and the society to grow young teak trees (Sun, M. et al., 2003). In this case, it is involved with the creative design to respond to customer requirements by disturbing the environments at the lowest level (Hallett, J. T. et al., 2011; Moisander, J. et al., 2010; Egwutvongsa, S., 2021).

According to the assessment results of the satisfaction to the customer groups with the young teak model for the internal decoration as the residents, it was found that the customer groups had satisfaction at the excellent level in eight fields. Then, designing and creating with the utilization guideline of the young teak trees could generate positive feelings among the customers by using the model at a suitable level. In this case, it can follow the objective of the designers by creating positive attitudes among the customers with the new products as the strategy principle for responding to the requirements at the highest level (Bloch, P. H., 2011). Furthermore, it involved planning to develop the utilization guideline for the young teak with sustainability (Dangelico, R. M., 2017). Further, the design guideline is beneficial to the communities and society from cultivating the economic teak trees with good effectiveness.

Based on the aforementioned, it is a natural learning guideline with customer requirements to solve the problems of thinking and the responding actions (Luchs, M. \& Swan, K. S., 2011; Wang, J. et al., 2021). It is similar to the market plan for the young teak products by creating good strength in the future, including by promoting gains in manufacturing procedure development. As a result, there will 
be cutting from the wide spaces in the plots at a suitable level and higher effectiveness by increasing the economic value for agriculturist groups (Garvey, A. M., 2017; Panzone, L. A. et al., 2021; Abdullah,A. H. \& Abdillah, N., 2021; Arham, A. F., et al., 2021; Egwutvongsa, S. \& Seviset, S., 2021).

\section{Acknowledgements}

This research was achieved with financial support provided by the 2016-2017 fiscal year budget from the Faculty of Industrial Education and Technology, King Mongkut's Technology Ladkrabang, Bangkok, Thailand.

\section{References}

Abdullah, A. H. \& Abdillah, N. (2021). Heritage Value of the Malayness Socio-Cultural Symbols in Millennium Artist Series of Arts: A Research Analysis in Semiotics. Journal of Educational and Social Research, 11(4), 251265 .

Aleban, N. A. (2021). A Proposal for a National Social Program for Supporting the Elderly in Saudi Arabia. Journal of Educational and Social Research, 11(4), 319-330. https://doi.org/10.36941/jesr-2021-0098

Arham, A. F., Norizan, N. S., Norizan, M. N., Arham, A. F. \& Ibrahim, S. N. (2021). A SmartPLS Visiting to Knowledge Retention: A Study Among SMEs in Peninsular Malaysia. Journal of Educational and Social Research, 11(4), 84-96. https://doi.org/10.36941/jesr-2021-0079

Bloch, P. H. (2011). Product Design and Marketing: Reflections After Fifteen Years. Journal of Product Innovation Management, 28(3), 378-380. https://doi.org/10.1111/j.1540-5885.2011.00805.x

Bumgardner, M. S. \& Nicholls, D. L. (2020). Sustainable Practices in Furniture Design: A Literature Study on Customization, Biomimicry, Competitiveness, and Product Communication. Forests, 11(12), 1277. https://doi.org/10.339o/fi1121277

Clark, G., Kosoris, J., Hong, J. N. \& Crul, M. (2009). Design for Sustainability: Current Trends in Sustainable Product Design and Development, Sustainability, 1(3), 409-424. https://doi.org/10.339o/su1030409.

Conti, E. \& Chiarini, A. (2021). Design-driven innovation: exploring new product development in the home appliances and furniture industry. The TQM Journal, 33(7), 148-175. https://doi.org/10.1108/TQM-12-20200313

Dangelico, R. M. (2017). What Drives Green Product Development and How do Different Antecedents Affect Market Performance? A Survey of Italian Companies with Eco-Labels. Business Strategy and the Environment, 26(8), 1144-1161. https://doi.org/10.1002/bse.1975

Egwutvongsa, S. (2021). Influence Factors on Industrial Handmade Products Designed from Sugar Palm Fibers. Strategic Design Research Journal. 14(2), 456-470. https://doi.org/10.4013/sdrj.2021.142.06

Egwutvongsa, S. \& Seviset, S. (2021). Ideas for Creation: A Comparison of the Learning Results of Three-Dimensional Images between Active Learning and Child-Centered Education of Product Design Students. International Journal of Emerging Technologies in Learning, 16(11), 273-288. https://doi.org/10.3991/ijet.v16i11.21597

Egwutvongsa, S. (2021). Toys for children with the concept of STEM: study of the result from children's playing activities. Journal for the Education of Gifted Young Scientists, 9(2), 77-9o. https://doi.org/10.17478/jegys.849063

Egwutvongs, S., Setvisat, S. \& Pirumgran, T. (2021). Development of the Processing Procedure for Palm Fiber with Communities for Industrial Handmade Product Creation. Academic Journal of Interdisciplinary Studies, 10(3), 143-157. https://doi.org/10.36941/ajis-2021-0071

Garvey, A. M. (2017). Bolton LE. Eco-Product Choice Cuts Both Ways: How Proenvironmental Licensing versus Reinforcement is Contingent on Environmental Consciousness. Journal of Public Policy E Marketing, 36(2), 284-298. https://doi.org/10.1509/jppm.16.096

Gustafsson, S.I. (1995). Furniture design by use of the finite element method. Holz als Roh-und Werkstoff, 53, 25726o. https://doi.org/10.1007/so01070050084

Hallett, J. T., Díaz-Calvo, J., Villa-Castillo, J. \& Wagner, M. R. (2011). Teak Plantations: Economic Bonanza or Environmental Disaster?, Journal of Forestry , 109(5), 288-292. https: //doi.org/10.1093/jof/109.5.288

Howarth, G. \& Hadfield, M. (2006). A sustainable product design model, Materials \& Design, 27(10), 1128-1133. https://doi.org/10.1016/j.matdes.2005.03.016

Jiang, L., Cheung, V., Westland, S., Rhodes, P. A., Shen, L. \& Xu, L. (2020). The impact of color preference on adolescent children's choice of furniture. Color Research and Application, 45(4), 754-767. https://doi.org/10.1002/col.22507 
Kuys, J., Al. Mahmud, A. \& Kuys, B. (2021). A Case Study of University-Industry Collaboration for Sustainable Furniture Design. Sustainability, 13(19), 10915. https://doi.org/10.3390/su131910915

Lai, X., Tan, K. C. \& Xie, M. (2007). Optimizing product design using quantitative quality function deployment: a case study. Special Issue: Fourth International Conference on Quality and Reliability (ICQR2005), $23(1), 45-57$. https://doi.org/10.1002/qre.819

Liu, J., Kamarudin, K. M., Liu, Y. \& Zou, J. (2021). Developing Pandemic Prevention and Control by ANP-QFD Approach: A Case Study on Urban Furniture Design in China Communities. International Journal of Environmental Research and Public Health. 18(5), 2653. https://doi.org/10.339o/ijerph18052653

Luchs, M. \& Swan, K. S. (2011). Perspective: The Emergence of Product Design as a Field of Marketing Inquiry. Journal of Product Innovation Management, 28(3), 327-345. https://doi.org/10.1111/j.1540-5885.2011.00801.X

Mas, S. R., Masaong, A. K. \& Suking, A. (2021). School Principal Entrepreneurial Competency Development Model to Optimize Generating Production Unit Income. Journal of Educational and Social Research, 11(5), $109-122$. https://doi.org/10.36941/jesr-2021-0110

Moalosi, R., Popovic, V. \& Hickling-Hudson, A. (2010). Culture-orientated product design. International Journal of Technology and Design Education, 20, 175-190. https://doi.org/10.1007/s10798-0o8-9069-1

Moisander, J., Markkula, A. \& Eräranta, K. (2010). Construction of consumer choice in the market: challenges for environmental policy. International Journal of Consumer Studies, 34(1), 73-79. https://doi.org/10.1111/j.14706431.2009.00821.X

Obinna, F. P., Sunday, A. A. \& Babatunde, O. (2021). Ergonomic assessment and health implications of classroom furniture designs in secondary schools: a case study. Theoretical Issues in Ergonomics Science, 22(1), 1-14. https://doi.org/10.1080/1463922X.2020.1753259

Panzone, L. A., Ulph, A., Hilton, D., Gortemaker, I. \& Tajudeen, I. A. (2021). Sustainable by Design: Choice Architecture and the Carbon Footprint of Grocery Shopping. Journal of Public Policy E Marketing, 40(4), 463-486. https://doi.org/10.1177/07439156211008898

Poti, T., Seviset, S. \& Ekawutwongsa, S. (2020). Study and Development of the Process of Converting the Postal Jacket to Deteriorate for Apply to Products. Mediterranean Journal of Social Sciences, 11(4), 102-111, https://doi.org/10.36941/mjss-2020-0045

Purnomo, H., Guizol, P. \& Muhtaman, D. R. (2009). Governing the teak furniture business: A global value chain system dynamic modelling approach, Environmental Modelling $\mathcal{E}$ Software, 24(12), $1391-1401$. https://doi.org/10.1016/j.envsoft.2008.04.012

Raymond L. B. (2013). Branding natural resources: science, violence and marketing in the making of teak, Transactions of the Institute of British Geographers, 38(4), 517-530. https://doi.org/10.1111/tran.12006

Shree, D., Gupta, A. \& Sagar, M. (2017). Effectiveness of cause-related marketing for differential positioning of market entrant in developing market: An exploratory study in Indian context. Journal of Philanthropy and Marketing, 22(2), e1573. https://doi.org/10.1002/nvsm.1573

Sun, M., Rydh, C. \& Kaebernick, H. (2003). Material Grouping for Simplified Product Life Cycle Assessment. The Journal of Sustainable Product Design, 3, 45-58. https://doi.org/10.1023/B:JSPD.0000035558.27697.02

Van-Nes, N. \& Cramer, J. (2005). Influencing product lifetime through product design. Special Issue: Sustainability and Design, 14(5), 286-299. https://doi.org/10.1002/bse.491

Wanneng, P., Ozarska, B., \& Daian, M. (2014). Physical Properties of Tectona Grandis Grown in Laos. Journal of Tropical Forest Science, 26(3), 389-396. http://www.jstor.org/stable/43150921

Wang, J., Yang, X., Bailey, A. \& Wang, J. (2021). Positive spillover of consumers' sustainable behaviors: The mediating role of self-determination need satisfaction. Journal of Cleaner Production, 317, 128436. https://doi.org/10.1016/j.jclepro.2021.128436

Xiong, X., Ma, Q., Yingying, Y., Wu, Z. \& Zhang, M. (2020). Current situation and key manufacturing considerations of green furniture in China: A review. Journal of Cleaner Production, 267, 121957. https://doi.org/10.1016/j.jclepro.2020.121957 